\title{
Entre a ruína e a obra de arte: psicossociologia da percepção da cidade histórica turística
}

\author{
Arley Andriolo \\ Universidade de São Paulo
}

\begin{abstract}
Resumo
Este artigo objetiva discutir o processo de significação da cidade histórica turística de Ouro Preto. Desenvolvese por meio de uma pesquisa em psicologia social baseada na fenomenologia e no estudo micro-histórico da percepção. O trabalho foi baseado em extensa pesquisa de artigos, livros e outras fontes sobre a cidade de Ouro Preto. Ao final, mostram-se os diferentes discursos concernentes a quatro campos perceptivos criados durante o século XX.
\end{abstract}

Palavras-chave: fenomenologia; turismo cultural; patrimônio histórico; Ouro Preto

\begin{abstract}
Between the ruin and the work of art: social psychology of touristic-historic city perception. This article aims to discuss the signification process of the tourist-historic city of Ouro Preto. It is developed through a social psychology research based on a phenomenological approach and a micro-historical study of perception. It was based on an extent research on articles, books and others documents about Ouro Preto city. At the end, one shows the different discourses concerning four main perception fields created during the $20^{\text {th }}$ century.
\end{abstract}

Keywords: phenomenology; cultural tourism; historic patrimony; Ouro Preto

$\mathrm{N}$ a metade do século passado, Ronai (1953) realizou mais uma de suas viagens a Minas Gerais. Ao retornar, deixou registrado um fato que se revelou sintético da condição contraditória de Ouro Preto naquele momento. Conta-nos o autor que um velho sobrado na Rua Antônio de Albuquerque estava sob a guarda da viúva de seu antigo proprietário. Seu valor histórico era reconhecido e, apesar de estar em estado precário, o Patrimônio Histórico e Artístico Nacional teria oferecido uma quantia razoável pelo imóvel. No entanto, a senhora não admitia o valor julgando-o muito inferior ao merecido por uma herança tão preciosa. O motivo alegado para não realizar a transação comercial era uma imagem do sobrado, retratada em pequena pintura; dizia-se que o autor do quadro ganhou o dobro daquilo que ofereciam a ela. Conforme Ronai, a senhora dizia indignada: "Se a mera imagem do sobrado valia isso, quanto não havia de valer o próprio sobrado, com paredes, janelas, e até um pedaço de telhado?". Aguardando a ascensão do preço, a viúva presenciou o desmoronamento de sua valiosa herança.

Essa historieta fornece uma indicação. Um mesmo objeto, seja um edifício, seja uma cidade, está submetido a percepções diferentes, as quais se organizam em função de valores simbólicos distintos. Neste caso, a percepção é compreendida como um processo que transcende às relações físico-químicas dos sentidos, para atingir uma ordem simbólica constituída na vida em sociedade. Merleau-Ponty (1999) notou a formação de um "arco intencional", o qual dispõe o sujeito encarnado numa situação que, além de espacial e temporal, abriga as dimensões intersubjetiva, social e histórica. $\mathrm{O}$ conceito de intencionalidade remete a E. Husserl, para quem intencionar é doar sentido, é visar algo ausente; portanto, trata-se de uma relação originária e simbólica.

Este texto terá por objetivo principal expor os significados decorrentes dos modos de perceber localidades reconhecidas como "cidades históricas", especificamente, Ouro Preto, Minas Gerais. Embora não seja novo, esse campo de estudos está difuso entre pesquisadores de áreas diferentes, historiadores, arquitetos, turismólogos e geógrafos. A proposta destas páginas é apresentar uma vertente de pesquisa suscitada pela Psicologia Social, particularmente, balizada pela filosofia fenomenológica (Dufrenne, 1953; Frayze-Pereira, 2004; Merleau-Ponty, 1999).

A história das formas de perceber tem sido objeto de muitos estudos, tendo em Lowe (1986), em sua síntese da história da percepção burguesa, um de seus proponentes. Crary (1990) apresenta as técnicas do observador oriundas do século XIX como dispositivos produzidos socialmente, os quais se tornam constitutivos da percepção porque organizam de modo particular as experiências corporais. A partir daí, as pesquisas analisam o objeto da percepção mediado pela cultura e pela história, a exemplo de Cosgrove e Daniels (2000), Meneses (2002), Roger (2000) e Schama (1996).

A tarefa de descrever as formas de percepção da cidade, neste texto, apóia-se em duas contribuições metodológicas. Por 
um lado, está a concepção de autores como Berger e Luckmann (1973), para os quais o conhecimento sobre as coisas e os lugares é uma construção social a ser descrita. Por outro, estão os estudos de micro-história, particularmente de Ginzburg (1991), em uma prática de pesquisa descritiva em consideração ao particular, partindo de índices emergentes ao longo do exame das fontes e narrativas. Realizou-se um inventário das narrativas, artigos e livros que se dedicaram à cidade de Ouro Preto. Em seguida, identificaram-se as categorias hegemônicas que possibilitariam circunscrever os principais campos da percepção sobre a cidade.

\section{A “cidade histórica”": perspectivas}

Com a mudança da capital mineira para Belo Horizonte, em 1897, desceu mais uma densa névoa sobre Ouro Preto, porém, daquela vez, muitos anos foram necessários até que as suas construções, igrejas, ruas e espaços públicos ganhassem visibilidade. Nos depoimentos tocantes de antigos moradores, captados de maneira exemplar por Barbosa (1993), esse momento de ruína pode ser relembrado. Décadas se passaram nas regiões de mineração desde o fastígio do ouro. Durante o século XIX, a economia das Minas estabilizara-se, a produção aurífera restringiu-se a algumas localidades e as fazendas de gado esparramaram-se pelo território (Iglésias, 1993). Em vários povoados setecentistas, restaram poucos habitantes zelando por templos magníficos cercados por escassas residências. Veja-se, por exemplo, os distritos de Ouro Preto, Cláudio Manuel e São Bartolomeu, cujas construções receberam novos e improvisados materiais para corrigir o desgaste do tempo. O "neoclássico", praticado na forma eclética, enquanto estética dominante nos oitocentos, foi em grande parte meio para o esquecimento, por meio do qual as formas da arquitetura setecentista, grandiosas ou de simples construção, não figuravam na memória nacional.

A valorização de Ouro Preto perpassou as dimensões dos discursos, das imagens e das representações. No início do século $\mathrm{XX}$, tanto as construções quanto os seus retratos, representavam um valor financeiro ínfimo aos seus proprietários, num momento em que a apropriação simbólica da cidade não principiara. O turismo brasileiro começou sua organização empresarial apenas nos anos 1950, quando as atividades ligadas às viagens possibilitaram uma exploração comercial durável.

A conhecida "cidade histórica" deste início do século XXI é o resultado de uma produção histórica e psicossocial complexa, iniciada timidamente em 1911, com a valorização local de algumas tradições. As tradições pré-existentes, denominadas de genuínas por Hobsbawm e Ranger (1984), foram conservadas no seio da comunidade, mas seguidamente reinventadas por outras tradições com o desenvolvimento da historiografia e das atividades turísticas no Brasil. Para Hobsbawm e Ranger (1984), tradição inventada é

um conjunto de práticas normalmente reguladas por regras tácita ou abertamente aceitas, tais práticas, de natureza ritual ou simbólica, visam inculcar certos valores e normas de comportamento através da repetição, o que implica, automaticamente, uma continuidade em relação ao passado. (p. 9)

S. Vasconcellos (1941a) já notara os copiosos erros nas descrições históricas de viagens a Minas Gerais: “Assim, vão os nossos viajantes, por apressados uns e mal orientados outros na coordenação dos fatos, tecendo aos poucos e desavisadamente uma nova história para as nossas cidades coloniais" (p. 1).

As tradições genuínas, as obras arquitetônicas e os espaços urbanos de Ouro Preto se encontravam em situação de ruína no início do século XX. A antiga capital era desenhada em oposição à cidade de Belo Horizonte, projetada sob o signo da modernização, enquanto àquela reservara-se o sinal do "atraso" (Damasceno, 1994). Barreto (1936) escreveu que não havia motivos para se duvidar da mudança da capital mineira para Belo Horizonte, pois,

Ouro Preto não oferece uma só das condições precisas para a capital de uma província tão importante como esta. Poderia descrever a sua decadência, mas que necessidade tenho eu de apresentar-vos esse quadro, quando o original está aí a nossa vista; quando aí se vos apresentarão as ruínas... (p. 205)

As ruínas, materiais ou imateriais, foram o ponto de partida para a elevação de Ouro Preto à condição de bem simbólico. Esse processo corresponde bem à consideração de Castoriadis (1982), segundo a qual todo simbolismo é edificado sobre as ruínas dos edifícios simbólicos precedentes. Nesse sentido, "por suas conexões naturais e históricas virtualmente ilimitadas, o significante ultrapassa sempre a ligação rígida a um significado preciso, podendo conduzir a lugares totalmente inesperados" (Castoriadis, 1982, p. 147).

A cidade é um artefato, produzido socialmente de modo complexo, em relação ao tempo e ao espaço. Para Lefebvre (1969), a cidade não é um objeto qualquer, mas uma obra, exigindo que se a considere como uma obra de arte: "a cidade é uma mediação entre as mediações" (p. 47). Esse autor notou os indícios resultantes da ordem distante, das ideologias e representações, a se projetarem na realidade sensível do espaço urbano:

Ela se situa num meio termo, a meio caminho entre aquilo que se chama de ordem próxima (relações dos indivíduos em grupos mais ou menos amplos, mais ou menos organizados e estruturados, relações desses grupos entre eles) e a ordem distante, a ordem da sociedade, regida por grandes e poderosas instituições (Igreja, Estado), por um código jurídico formalizado ou não [morais], por uma 'cultura' e por conjuntos significantes. (Lefebvre, 1969, p. 47)

As imagens e discursos acerca da "cidade histórica" ganham materialidade e dimensão espacial na cidade turística. Os conhecimentos sobre arquitetura e infra-estrutura urbana também se projetam sobre a cidade real, para usar a formulação de Argan (1992), "sempre existe uma cidade ideal dentro ou sob a cidade real, distinta desta como o mundo do pensamento o é do mundo dos fatos" (p. 73). Assim, também escreveram Ashworth e Tumbridge (1990), afirmando a existência de várias cidades na cidade, tais como a cidade dos arquitetos, a dos vereadores, a dos planejadores urbanos e a do turista. De todas estas formas de perceber, a "cidade do habitante", distinta daquela idealizada pelos legisladores, carece de força simbólica para se fazer visível. Nesse sentido, as várias perspectivas possíveis acerca da cidade 
apresentam-se nas relações de força dos grupos sociais, locais ou distantes, cuja ordenação se dá tanto no plano das idéias quando no espaço urbano.

Admitindo o campo do turismo, as agências, operadoras de viagens e as instâncias governamentais envolvidas com o setor, como representantes da ordem distante, têm-se também os grupos sociais locais como representantes da ordem próxima. A produção social da cidade é o resultado das lutas por representações, sob ordens diversas, as quais se manifestam nas percepções dos sujeitos. A "cidade histórica" conhecida é a cidade ideal hegemônica. As lutas de representação pela ordenação da estrutura social baseiam-se naquilo que Chartier (1991) chamou de "estratégias simbólicas que determinam posições” (p. 183).

\section{A cidade histórica turística}

Nesse contexto, os atrativos turísticos são estruturas artificiais ou naturais que ganham significado junto a centros consumidores, tornando-se motivadores de viagens e cumprindo um papel de mediação. O campo turístico, com seus elementos constitutivos - meios de hospedagem, operadoras de viagens, etc. -, é um campo de produção e promoção de produtos, mas também de reprodução, em que os bens simbólicos, resultantes do trabalho intelectual e de seus conflitos (Bourdieu, 1992), são apropriados e reelaborados. As relações de força entre as perspectivas dos grupos sociais adjudicam a existência dos atrativos.

Abordar a "cidade histórica" do ponto de vista da Psicologia Social não será, portanto, localizar a "descoberta" de um atrativo privilegiado para a percepção cultivada ou para o olhar do turista, mas antes descrever a sua gênese enquanto objeto da percepção de espectadores diversos, de modo a compreender como os intelectuais, a imprensa, os agentes de turismo, entre outros, participam da produção de representações sociais da cidade. O campo do turismo, que desde as décadas de 1950 e 1960 organizava as atividades ligadas a viagens, encontrou uma situação favorável a seus projetos produtivos, de antemão operada por estudiosos que visitavam as "cidades históricas".

Desta feita, aquilo que se denomina hoje como "cidade histórica turística" não é apenas um pólo receptor de turistas ou um espaço geograficamente definido onde residem atrativos e infra-estrutura turísticos. Embora importantes, esses elementos não esclarecem a condição de uma cidade definida como "histórica e turística". A percepção de uma localidade não é um dado natural; assim, é impossível ser compreendida em sua condição intrínseca, senão como relação entre aqueles que percebem e o objeto da percepção.

Portanto, existem duas adjetivações vinculadas ao termo cidade que devem ser investigadas (Ashworth \& Tumbridge, 1990). As relações fundamentam-se inicialmente no primeiro termo - histórica - que indica um julgamento e atribuição de valor a objetos, estruturas urbanas, ou fatos imateriais (como a "Inconfidência" e o "Tiradentes"), os quais são gerados no campo da produção erudita, para depois serem recebidos pela coletividade e tornados experiências sociais. A história é apreendida e direcionada pela segunda adjetivação - turística. Isoladamente, os valores históricos não são capazes de mobilizar uma quantidade considerável de consumidores na consolidação de um produto turístico. Para isso, é importante a construção de uma infra-estrutura turística que redireciona e reforça aquela condição e cria possibilidades de uso e apropriação da cidade para o turismo.

Admite-se a existência de uma interface entre o campo da produção erudita e o campo do turismo, possibilitando a constituição de produtos turísticos. Os discursos e documentos visuais produzidos pelos intelectuais são extraídos de seu campo originário e reproduzidos conforme as necessidades do campo turístico. No entanto, os significados são utilizados apenas em parte, não somente reproduzidos de modo imediato, passam por interesses de grupos hegemônicos do próprio campo turístico. Assim, a "cidade histórica turística" emerge desde a sua gestação nos escritos dos viajantes, da apreciação de estudiosos, passando pelo redirecionamento imprimido segundo os interesses de agenciadores do turismo e governantes, para se tornar então objeto da percepção do turista.

A chamada motivação, em turismo, reside na produção e reprodução de documentos visuais e discursivos que fundamentam o ato de viajar, estimulando o consumo do produto turístico na percepção do objeto representado. São providos de grande conteúdo simbólico, tanto no plano do discurso quanto na produção material de retratos e fotografias. A eficácia de um objeto enquanto motivador turístico está na sua participação e fixação junto ao público. Assim, a abordagem psicossocial das cidades turísticas põe em questão a dualidade de posições que ora atribuem o deslocamento de pessoas à força do atrativo turístico, ora se concentram na opressão das grandes cidades e na consolidação de mercados, para buscar entre ambas um conjunto de experiências sócio-históricas que preencham o campo da percepção.

A compreensão de um objeto complexo como a "cidade histórica" não pode ser atingida sem um questionamento dos significados que encerra. Em Ouro Preto, a questão do significado apresenta-se desde a mudança da capital mineira para Belo Horizonte, mas é a partir de seu tombamento, em 1933, que a cidade passa a ser tratada como um monumento, desconsiderandose sua dinâmica própria e de seus habitantes (Motta, 1987). Daí a importância das políticas culturais implementadas desde então na cidade (R. Machado, 1976; Queiroz, 1984).

\section{Experiência social e campo da percepção}

Pensar essa questão a partir das diversas percepções permite percorrer o espaço entre a produção e a recepção dos bens simbólicos, bem como entre planos individuais e coletivos da experiência social. Dentre as múltiplas realidades que se oferecem ao sujeito, escreveram Berger e Luckmann (1973), a realidade da vida cotidiana é a predominante. Essa realidade é experimentada como objetivada antes de mim e com duração além de mim, mesmo que esteja "organizada em torno do aqui de meu corpo e do agora de meu presente" (Berger \& Luckmann, 1973, p. 38).

Baseado em noções fenomenológicas, ao escrever sua História da percepção burguesa, Lowe (1986) considerou o campo perceptivo como um campo horizontal, "porque o sujeito o enfoca perspectivamente, desde o íntimo e familiar 
até o distante e tipificado, com a intenção de viver" (p. 31). O campo perceptivo constitui-se pelo espectador, o ato de perceber e o conteúdo do percebido. Esse autor propõe circunscrever as transformações temporais e espaciais do campo perceptivo a partir dos meios de comunicação, da hierarquia dos sentidos e dos pressupostos epistemológicos que ordenam o mundo do conhecimento. Nas palavras de Lowe (1986),

Em cada período a cultura dos meios de comunicação forja um ato de perceber; o sujeito fica delimitado por uma diferente organização hierárquica dos sentidos e o conteúdo do percebido oferece a ele um conjunto distinto de regras epistêmicas. Por conseguinte, o campo perceptivo constituído é uma formação histórica, que difere entre um período e o seguinte. (p. 31)

Além disso, embora seja possível à historiografia circunscrever esses campos genéricos e seus processos de transformação, deve-se lembrar que residem sob os campos perceptivos hegemônicos outros campos, dotados de modos de perceber subalternos. Num determinado momento, coexistem sedimentos de campos perceptivos antigos e novos campos em conflito com as orientações dominantes (Lowe, 1986). Desse modo, sem perder de vista as particularidades de cada percepção para a cidade, nota-se que existem posições hegemônicas que são mais ou menos compartilhadas.

As descrições de viagens, os guias turísticos, artigos de jornais e revistas de divulgação, com suas "estratégias de escrita e decisões editoriais", nos termos de Chartier (1991), são ao mesmo tempo perspectivas pontuais articuladas a experiências sociais. Por um lado, essas leituras sugerem uma viagem que se poderia designar "imaginária", por outro, orientam a realização do deslocamento pelo território; portanto, configuram formas de perceber as ruas, o casario, a paisagem. Não obstante a percepção do turista ser maior que as práticas turísticas, uma vez que "é construída e mantida por uma variedade de práticas não-turísticas, tais como o cinema, a televisão, a literatura" (Urry, 1996, p. 18), o estudo dos textos que participam da constituição das diversas formas de perceber Ouro Preto permite a apreensão necessária dos problemas aqui enunciados, embora deixem transparecer os limites da pesquisa, pois existem formas de perceber que não são compreendidas nos registros escritos, as quais solicitam outros procedimentos de coleta de dados, tais como entrevistas com moradores e turistas. Neste trabalho, a delimitação de fontes foi pautada unicamente em fontes escritas.

\section{Campos da percepção de Ouro Preto}

A pesquisa baseou-se em fontes localizadas em arquivos de Ouro Preto (na Biblioteca Municipal e na Casa do Pilar, mais conhecida como Museu da Inconfidência), Belo Horizonte (na Hemeroteca Pública de Minas Gerais), São Paulo (no Arquivo Público do Estado de São Paulo e na Biblioteca Municipal), Rio de Janeiro (no Arquivo Noronha Santos do Instituto do Patrimônio Histórico e Artístico Nacional). A esse conjunto documental aplicou-se uma organização cronológica e a identificação de categorias que indicam formas de perceber. A partir desses indícios, formularam-se eixos de duração e transformação, os quais possibilitam a apreensão do processo de significação e conseqüente configuração de campos de percepção. Serão descritos de modo sintético os discursos coletados acerca da cidade de Ouro Preto, com vistas a apresentar os principais campos perceptivos formulados ao longo do século XX, indicados como: cidade em ruínas, cidade monumento nacional, cidade das obras de arte e cidade histórica turística.

\section{A cidade em ruínas}

Durante o processo de transferência da capital mineira para Belo Horizonte, emergiu uma série de discursos contrários a Ouro Preto, considerando-a imprópria para abrigar uma capital moderna. Nas palavras da população, que não se beneficiou da oferta de terrenos em Belo Horizonte, a exemplo daquelas proferidas por dona Erothides Esteves Vieira (1894-1987; nascida em Ouro Preto, no bairro Água Limpa), "Ouro Preto era muito triste" naquele início de século, "depois disso ficou muita casa sem valor (desalugada) assim como esta mesma aí em baixo ficou desalugada. Ouro Preto ficou vazio, mamãe contava que ficou bem vazio Ouro Preto" (citado por Barbosa, 1993, p. 21).

Configurou-se um campo que se poderia designar a cidade em ruínas. Mencionou-se o termo ruína no pronunciamento de Barreto (1936), mas sem o bucolismo de viajantes, tais como Nascentes (1923), que falava de "Ouro Preto com suas ruínas" (p. 307). Em ambos, não se tratava do significado nacional ou artístico, outrossim, da antiguidade do local. Um antigo morador de Ouro Preto, o sapateiro e ferroviário José Alves dos Santos Júnior, lembra-se:

Antes de 1930, a cidade aqui era uma cidade fracassada. [...] A cidade, naquela época, não tinha vida, era difícil para trabalhar, não havia indústria, não havia nada. Todo mundo foi saindo. [...] De 1915 para cá é que começou a sofrer um progressozinho, com a vinda de uma unidade do Exército que foi criada aqui. (citado por Barbosa, 1993, p. 27)

Nesta narrativa, encontram-se os dois marcos referentes à transição da percepção da cidade. Mais precisamente, desde 1911, com as comemorações do bicentenário da elevação de Vila Rica e a promoção da localidade, assinalava-se o interesse de grupos locais. Estes convergiram com o programa nacionalista dos primeiros anos do Governo Vargas, cujo resultado maior foi a monumentalização da cidade de Ouro Preto, em 1933.

Antes da efetivação desse processo, pode-se identificar dizeres importantes. Pinto (1907, p. 693), lançava uma apreciação que, embora não a considerasse "bonita", a "gloriosa Ouro Preto" era referida em seu "aspecto pitoresco", esboçando um guia de visitação à cidade. O historiador ouropretano D. Vasconcellos (1911/1934) lembrava aos patrícios que "mesmo quando a fatalidade das circunstâncias fizesse eclipsar a civilização, bastaria o testemunho mudo de nossas ruínas para reatar o passado ao futuro..." (p. 102). Fundamentava-se o significado dessas ruínas, como diria pouco depois Lima (1916), nos heróis da Inconfidência que vislumbraram uma pátria livre.

Imbuído desse sentido, o argentino Loudet (1922) viajava pelo Brasil. Diante dele, a cidade erguia-se "maravilhosa" em suas perspectivas inesperadas. Tomado de emoção, Loudet não resiste apenas em olhar e, munido de um canivete, destaca um 
pedacinho de madeira "da janela dos suspiros de Tomás Antônio Gonzaga" (p. 134), à guisa de lembrança. Ouro Preto tornava-se a janela consagrada, pela qual se vislumbraria o passado.

\section{A cidade monumento nacional}

Durante o início do período Vargas criaram-se os primeiros órgãos oficiais destinados à preservação do patrimônio nacional - Inspetoria dos Monumentos Nacionais, 1934; Serviço do Patrimônio Histórico e Artístico Nacional - SPHAN (1937), sob os auspícios do Ministério da Educação e Cultura, articulando explicitamente a função pedagógica e o ato de viajar (Andriolo, 2002). A publicação de guias de viagem aparece como atividade relevante naquele momento. Dois exemplares desse gênero foram escritos por Gilberto Freyre e dedicados à cidade do Recife e Olinda, nos anos de 1934 e 1939, respectivamente. Entre as publicações financiadas pelo Governo Federal naqueles anos, por intermédio do SPHAN, encontra-se um guia da cidade de Ouro Preto, escrito por Bandeira (1938).

Este último tem grande significado no contexto de sua produção. O Ministério da Educação e Saúde tomou para si os encargos de levar ao público a literatura de interesse nacional. Entre os temas, encontravam-se, por exemplo, a Inconfidência Mineira, Tiradentes e os exilados. Ao estudar a recepção das "Cartas Chilenas", o historiador Furtado (1997) observou que não foram casuais certas iniciativas editoriais no Estado Novo, "apelando à liturgia cívica em tempos de intensa reafirmação da identidade nacional" (p. 121). Coube à Imprensa Nacional a primeira edição dos "Autos da Devassa da Inconfidência Mineira" (entre 1936 e 1938). Criou-se também nesses anos a revista do SPHAN, em 1937, coleção de "referência básica para os estudos sobre a arte e arquitetura brasileiras" (Andrade, 1993, p. 113). Por meio dessa revista, foram veiculados estudos sobre Ouro Preto, dentre os quais, os de Macedo (1937) e S. Vasconcellos (1941b).

O guia de Bandeira (1938) foi uma obra encomendada pelo SPHAN; a de número dois. Ali, o autor defende que o principal período da vila iniciara-se com as construções de pedra nos grandes edifícios, "a construção do Palácio novo marca o início da boa arquitetura de pedra argamassada" (Bandeira, 1938, p. 20). Lembrando Le Corbusier, Andrade (1993) indaga que "nem todo o passado tem direito, por definição, à perenidade..." (p. 117). No caso ouropretano, ao circunscrever-se um tempo determinado, delimitava-se os objetos com direito à preservação e conseqüentemente à percepção das gerações vindouras.

Junto à valorização das construções de pedra, forjava-se um conceito para a arte colonial de Minas Gerais, articulando as obras da cidade e a memória nacional: "Para nós brasileiros, o que tem força de nos comover são justamente esses sobradões pesados, essas frontarias barrocas, onde alguma coisa de nosso começou a se fixar. A desgraça foi que esse fio de tradição tenha se partido" (Bandeira, 1938, p. 42). A cidade ganhava projeção, em seu caráter simbólico nacional. O autor considerava-a única, tanto pela arquitetura que abrigava quanto por sua dimensão patrimonial: "De todas as nossas velhas cidades é ela talvez a única destinada a ficar como relíquia inapreciável do nosso passado" (Bandeira, 1938, p. 45).

O campo da cidade monumento nacional encerra sua particularidade por ser o momento privilegiado das práticas do SPHAN, na afirmação de Motta (1987), com uma série de intervenções destinadas à restauração do facies colonial, ordenando uma prática que se iniciara com os decretos do prefeito João Velloso e com a Inspetoria dos Monumentos Nacionais. Datam ainda desse período a publicação do "Roteiro lírico de Ouro Preto", de Franco (1937/1980), a inauguração do Museu da Inconfidência (1944) e a construção do Grande Hotel Ouro Preto (1945).

Desde os primeiros atos de preservação, procede-se a uma vinculação do patrimônio ouropretano ao culto à Nação, seja frente a uma "cidade sagrada", nos termos de Barroso (1928/1944), seja do "berço da Independência", conforme indicado no pronunciamento do Ministro Protógenes Pereira Guimarães (Instituto Histórico de Ouro Preto, 1936). Ouro Preto foi alçada monumento nacional no dia 12 de julho de 1933, pelo decreto no 22.928 (Brasil, 1933, s/p):

Considerando que é dever do poder público defender o patrimônio artístico da Nação e que fazem parte das tradições de um povo, os lugares em que se realizaram os grandes feitos de sua história. Considerando que a cidade de Ouro Preto, antiga capital do Estado de Minas Gerais foi teatro de acontecimentos de alto relevo histórico na formação de nossa nacionalidade e que possui velhos monumentos, edifícios e templos de arquitetura colonial, verdadeiras obras de arte, que merecem defesa e conservação.

\section{A cidade das obras de arte}

O campo da cidade monumento nacional persiste nos períodos subseqüentes, podendo ser notado em discursos que se prolongam até os dias de hoje. Mas, a frase "verdadeiras obras de arte", do decreto de 1933, emerge como enunciado, sobretudo, a partir da década seguinte, quando se pode identificar o campo da cidade das obras de arte.

A menção à arte, comumente referendada nos textos de D. Vasconcellos (1911/1934) e Mattos (1935), aparecia noutras citações ligando a cidade de Ouro Preto a um discurso de exceção. Por exemplo, tratava-se da "única cidade de arte" no Brasil, em Loudet (1922, p. 128), Taunay (1926, citado por Racioppi, 1936, p. 50) e Washington Pires (1933, citado por Gravatá, 1975, p. 105). Não obstante, nos anos 1950, nos estudos de L. Machado (1949), Santos (1951) e S. Vasconcellos (1956/1979), a arte ouropretana tem um lugar reservado. Como escreveu L. Machado (1978), a cidade é "um reino quase absoluto do barroco" (p. 197). No início dos anos 1970, podia-se ler na imprensa o termo composto "cidade barroca" para se referir a Ouro Preto (Andrade, 1972).

Uma questão importante desse campo é a reprodutibilidade de imagens da cidade em livros ricamente ilustrados. O guia de Bandeira (1938) trazia significativos desenhos de Luís Jardim, participante do movimento regionalista do Nordeste, porém, desde 1941, os ensaios fotográficos de Edgard de Cerqueira Falcão chegavam às livrarias, com o objetivo primordial de divulgar imagens. Após sua primeira publicação, Relíquias da Bahia, ele partiu para o território mineiro, em um roteiro idealizado por Rodrigo Mello Franco Andrade, então diretor do 
SPHAN, cujo resultado foi o ensaio Relíquias da terra do ouro (Falcão, 1946).

Nesse percurso, notam-se as "cidades históricas de Minas" - Mariana, Ouro Preto, São João del Rei, Tiradentes, Congonhas e Sabará. Foi uma viagem de 20 dias, entre agosto e setembro de 1943, quando realizou todas as fotografias necessárias à publicação (do total de 700 , foram publicadas 383 ). O texto foi escrito posteriormente, contendo breve histórico da região e das cidades visitadas. Seu companheiro de viagem, Rodolfo Armin Freudenfeld, elaborava um trabalho sobre o mestre Antônio Francisco Lisboa. Contou também com a colaboração de Dom Helvécio Gomes de Oliveira, arcebispo de Mariana, organizador do Museu de Arte Sacra dessa cidade.

L. Machado (1958) resenhou o livro, afirmando que, das publicações feitas com material fotográfico, Relíquias teria sido a mais volumosa disponível no mercado literário. A singularidade da obra fundamentou-se em seu pioneirismo, na sua finalidade de registro da produção artística com fins documentais. Nas palavras de L. Machado (1958):

O melhor atestado desse bom sucesso está, sem dúvida, na rapidez com que 'Relíquias da Terra do Ouro' desapareceu das livrarias, tornando-se raridade bibliográfica. Convirá, contudo, esclarecer que tão rápida dispersão não se deve apenas ao fato de tratar-se de um belo livro sobre coisas belas, senão também e principalmente porque o livro constituiu o primeiro volume de segura e ampla referência visual sobre a arte de Minas. (p. 6)

Tais fotografias de tipo documental - de acordo com L. Machado (1958), documentos "exatos e fiéis", protegidos pela objetividade no seu padrão "frontal e simétrico" (p. 6) -, permitiram que as imagens das cidades mineiras se revestissem de uma função cognitiva em relação à própria história da arte brasileira.

Nesse livro, Ouro Preto foi contemplada com 172 fotografias, o que equivale a $45 \%$ do total. Dois edifícios receberam a maior quantidade de registros: a Igreja de Nossa Senhora do Carmo (com 32 fotos), e a Igreja de São Francisco de Assis (com 28). Para as matrizes foram 13 tomadas; os objetos (religiosos ou profanos) tiveram 44; todas as outras igrejas juntas perfizeram um total de 19 registros, enquanto a arquitetura civil, incluindo o Palácio dos Governadores e Casa de Câmara e Cadeia, teve 9. O restante das imagens da cidade (37) dividiu-se entre "Passos da Paixão", pontes, chafarizes e vistas panorâmicas.

Quando as imagens registradas começaram a direcionar o olhar, o turismo de massa ainda não havia se estabelecido no país. Num sentido mais amplo, enquanto a imagem fotográfica ganhava um lugar junto aos documentos visuais da "cidade histórica", formava-se um modelo para a percepção do turista.

\section{A cidade histórica turística}

Dos cinqüenta e seis livros dedicados a Ouro Preto ao longo do século XX e inventariados durante a pesquisa, um número significativo apareceu na década de 1950: onze títulos. Nas décadas seguintes, o número decresce, mas nunca abaixo de cinco publicações a cada dez anos, para novamente atingir um pico na década de 1980, com quatorze livros. O interesse do mercado editorial pela cidade resulta tanto de pesquisas históricas, arquitetônicas e urbanísticas, quanto de publicações vinculadas ao mundo das viagens e do turismo.

Dentre os títulos publicados nas décadas de 1940 e 50, o SPHAN levou às livrarias o trabalho de Lopes (1942), iniciando uma abordagem sobre construções específicas da cidade, ao lado das compilações documentais de R. Trindade (1951). Nesse período, foi lançado em Lisboa o trabalho de Krull (1943), com prefácio de Raul Lino, e um guia por G. Trindade (1948). Data de 1950 a primeira edição do escrito de Eponina Ruas, diretora da Sociedade Amigos de Ouro Preto, uma brochura que além de servir como guia - pois "escrito para facilitar os que nos visitam" (Ruas, 1950, p. 37) -, descrevia aspectos detalhados da história e dos monumentos. Note-se, ainda, o importante trabalho Vila Rica, formação e desenvolvimento - residências, de S. Vasconcellos (1956/1977), e as polêmicas fomentadas por Lima Júnior (1957/1996).

Na bibliografia pesquisada, cerca de $25 \%$ das publicações sobre Ouro Preto eram oriundas da própria cidade, outros $25 \%$ provenientes do estado de Minas Gerais (sobretudo Belo Horizonte). As cidades do Rio de Janeiro e São Paulo dividem quase $50 \%$ da produção editorial sustentando o significado de Ouro Preto, reservando uma pequena quantidade ao exterior. Tal situação refletia a própria visitação da cidade; conforme uma pesquisa realizada em 1976, 45,12\% dos turistas em visita a Ouro Preto provinham dos estados do Rio de Janeiro e de São Paulo, enquanto Minas Gerais comparecia com 30,98\% desse contingente (Cançado, 1976).

Embora a história do turismo no Brasil possa remeter às primeiras décadas do século XX o início da exploração das viagens, foi somente a partir da década de 1970 que a organização empresarial de agentes de viagens, operadoras, proprietários de hotéis e projetos governamentais consolidam o produto turístico cidades históricas de Minas. Considerando-se as publicações de livros, o aumento de hotéis e pousadas instalados na cidade, bem como a aparição da cidade nos cadernos de turismo, sugere-se a formação de um novo campo, a partir da década de 1970, a ser designado cidade histórica turística.

\section{Conclusão}

A compreensão dos campos que orientam a percepção da cidade tem por objetivo trazer à discussão as múltiplas perspectivas, por um lado, indicando a formação de campos hegemônicos, como acima descritos, por outro lado, abrindo possibilidades de expressão de discursos subjacentes. Nesse sentido, o tema cidade histórica turística abre-se a pesquisas psicossociais de orientação fenomenológica por possibilitar a apreensão da estrutura constitutiva da percepção da cidade em seu processo histórico de significação. A estrutura de significados é dinâmica e se expressa nas formas de perceber dos vários autores investigados, as quais se organizam socialmente nos campos de percepção citados. Neste texto, à guisa de conclusão, apresenta-se uma síntese dos desdobramentos dos campos perceptivos em dois elementos centrais à percepção - espaço e tempo. 
Quanto à noção de espaço, tendo em vista que o turismo age sobre porções recortadas da cidade histórica, segundo uma lógica que envolve tanto as representações quanto a ocupação geográfica, a percepção desenvolve-se em setores social e historicamente definidos. Nesse sentido, os discursos sobre a cidade e sua arquitetura fomentam roteiros de visitação que valorizam determinados espaços. A questão de uso do solo, para Ashworth e Tumbridge (1990), é apenas a dimensão territorial de um problema maior: que história, que herança tem sido representada?

A setorização da cidade promovida pelo uso dos atrativos é resultado do processo de significação de determinados objetos, os quais são, ou não, inscritos nos roteiros turísticos. Esses setores são definidos por serem continentes de atrativos, pela proximidade de monumentos, ou devido a sua situação junto aos roteiros. Como objeto complexo Ouro Preto apresenta sobreposições de setores que representam tempos históricos distintos, os quais são representativos de diferentes momentos da experiência social local e nacional, bem como da permanência de monumentos (exceções) nos setores menos privilegiados.

Quanto à noção de tempo, o conhecimento histórico vulgarizado nas formas de perceber parece ocultar do espectador a diversidade de processos, reforçando, com base nas delimitações espaciais correspondentes, os recortes temporais hegemônicos; enfatizando, sobretudo, as décadas de meados do século XVIII. No entanto, a cidade é um artefato produzido socialmente em diversos momentos, o processo de significação retira-lhe sua historicidade vivida. Nas palavras de Aymonino (1984), a cidade é um lugar artificial de história no qual cada época tenta, "mediante a representação de si própria nos monumentos arquitetônicos, o impossível: assinalar aquele tempo determinado, para além das necessidades e dos motivos contingentes porque os edifícios foram criados" (p. 11).

Ao final da pesquisa, notou-se a configuração de quatro campos hegemônicos, os quais, embora constituídos em recortes cronológicos, não são fechados e prolongam-se uns nos outros Os discursos das últimas décadas do século XX indicam a "capital nacional do barroco" como forma hegemônica para a percepção de Ouro Preto. Não obstante, as pessoas do passado e do presente manifestaram modos de viver próprios, os quais se projetaram no espaço urbano e prolongam-se na cidade do século XXI em uma historicidade viva: Vila Rica; a Imperial Cidade de Ouro Preto; a Cidade Monumento Nacional; etc. Trata-se de processos temporais expressos no espaço urbano, a manifestar a diversidade da experiência social do lugar em tensão com aqueles campos hegemônicos.

\section{Referências}

Andrade, A. L. D. (1993). Um estado completo que pode jamais ter existido. Tese de doutorado não-publicada, Faculdade de Arquitetura e Urbanismo, Universidade de São Paulo, São Paulo.

Andrade, T. (1972, 7 de dezembro). Uma cidade barroca. O Globo, s/p.

Andriolo, A. (2002). Representações do passado histórico: viagens e educação nacional. Temporis (Ação), 1(5/6), 11-24.

Argan, G. (1992). História da arte como história da cidade. São Paulo: Martins Fontes.
Ashworth, G., \& Tumbridge, J. (1990). The tourist-historic city. Londres: Belhaven.

Aymonino, C. (1984). O significado das cidades. Lisboa: Presença.

Bandeira, M. (1938). Guia de Ouro Preto. Rio de Janeiro: Ministério da Educação e Saúde.

Barbosa, L. (1993). Memórias de Ouro Preto. Ouro Preto: Universidade Federal de Ouro Preto.

Barreto, A. (1936). Bello Horizonte, memória historica e descriptiva. Belo Horizonte: Rex.

Barroso, G. (1928, 31 de novembro). A cidade sagrada. Correio da Manhã. (Transcrito em Anais do Museu Histórico Nacional, v. 5, 1944, pp. 10-14).

Berger, P., \& Luckmann, T. (1973). A construção social da realidade: tratado de sociologia do conhecimento. Petrópolis: Vozes.

Bourdieu, P. (1992). Economia das trocas simbólicas. São Paulo: Perspectiva.

Brasil, Senado Federal. (1933, 12 de julho). Decreto n ${ }^{\circ}$ 22.928: Erige a cidade de Ouro Preto em Monumento Nacional. Diário Oficial da União, Rio de Janeiro. Disponível em: <http://www6.senado.gov.br/legislacao/ ListaPublicacoes.action? $\mathrm{id}=32122>$.

Cançado, J. (1976). Análise mercadológica do sistema turístico da cidade de Ouro Preto. Dissertação de mestrado não-publicada, Fundação Getúlio Vargas, São Paulo.

Castoriadis, C. (1982). A instituição imaginária da sociedade. Rio de Janeiro: Paz e Terra.

Chartier, R. (1991). O mundo como representação. Estudos Avançados, 11(5), 173-191.

Cosgrove, D., \& Daniel, S. (Orgs.). (2000). The Iconography of landscape: essays on the symbolic representation, design, and use of past environments. Cambridge: Cambridge University Press.

Crary, J. (1990). Techniques of the observer: on vision and modernity in the nineteenth century. Cambridge, Massachussets: MIT Press.

Damasceno, S. (1994). Pedras e sombras de Villa Rica. Dissertação de mestrado não-publicada, Pontifícia Universidade Católica do Rio de Janeiro, Rio de Janeiro.

Dufrenne, M. (1953). Phénoménologie de l'experience esthétique. Paris: Presses Universitaires de France.

Falcão, E. (1946). Relíquias da terra do ouro. São Paulo: Graphicar.

Franco, A. A. M. (1980). Roteiro lírico de Ouro Preto. Brasília: Editora Universidade de Brasília. (Publicado originalmente em 1937)

Frayze-Pereira, J. (2004). A dimensão estética da experiência do outro. Proposições, 15(1), 19-26.

Furtado, J. (1997). Uma república de leitores, história e memória na recepção das cartas chilenas (1845-1989). São Paulo: Hucitec.

Ginzburg, C. (1991). A micro-história e outros estudos. Rio de Janeiro/Lisboa, Bertrand/Difel.

Gravatá, H. (1975). Patrimônio histórico e artístico de Minas Gerais - conservação e proteção oficial. Barroco, 7, 101-121.

Hobsbawm, E., \& Ranger, T. (1984). A invenção das tradições. Rio de Janeiro: Paz e Terra.

Iglésias, F. (1993). Estrutura social do século XVIII. Anuário do Museu da Inconfidência, 50-57.

Instituto Histórico de Ouro Preto (1936). Uma Placa na Casa do Visconde. Primeiro Centenário do Visconde de Ouro Preto (1836-1936) - Instituto Histórico de Ouro Preto (pp. 24-25). Rio de Janeiro: Officinas Graphicas do Jornal do Brasil.

Krull, G. (1943). Ouro Preto: uma cidade antiga do Brasil. Lisboa: Atlântico.

Lefebvre, H. (1969). O direito à cidade. São Paulo: Documentos.

Lima, A. (1916). Pelo passado nacional. Revista do Brasil, 9(3), 1-15.

Lima Júnior, A. (1996). Vila Rica do Ouro Preto. Rio de Janeiro: EGL. (Publicado originalmente em 1957)

Lopes, F. (1942). História da construção da Igreja do Carmo de Ouro Preto. Rio de Janeiro: Ministério da Educação e Saúde/Serviço do Patrimônio Histórico e Artístico Nacional. 
Loudet, E. (1922). Ouro Preto, a cidade única. Revista do Brasil, 74, 125-137.

Lowe, D. (1986). Historia de la percepción burguesa. México: Fondo de Cultura Económica.

Macedo, E. (1937). A Capela de N. S. de Sant'Ana. Revista do Patrimônio, 1, 151-154.

Machado, L. (1949). Viagem a Ouro Preto. Separata da Revista do Arquivo. São Paulo, Departamento de Cultura.

Machado, L. (1958, 18 de janeiro). Um Pioneiro. O Estado de São Paulo, Suplemento Literário, p. 6.

Machado, L. (1978). Barroco mineiro. São Paulo: Perspectiva/Edusp.

Machado, R. (1976). Ouro Preto e Mariana: Uma análise da linguagem formal urbana. Barroco, 8, 13-20.

Mattos, A. (1935). Monumentos históricos, artísticos e religiosos de Minas Gerais. Belo Horizonte: Biblioteca Mineira de Cultura/Edições Apollo.

Meneses, U. (2002). A paisagem como fato cultural. In E. Yázigi (Org.), Turismo e paisagem (pp. 29-64). São Paulo: Contexto.

Merleau-Ponty, M. (1999). Fenomenologia da percepção. São Paulo: Martins Fontes.

Motta, L. (1987). A SPHAN em Ouro Preto: uma história de conceitos e critérios. Revista do Patrimônio Histórico e Artístico Nacional, 22, 108-122.

Nascentes, A. (1923). O turismo no Brasil. Revista do Brasil, 88(22), 305-307.

Pinto, M. (1907). Ouro Preto. Revista do Arquivo Público Mineiro, 11, 691714.

Queiroz, M. (1984). Ouro Preto e Mariana. In A. Arantes (Org.), Produzindo o passado, estratégias de construção do patrimônio cultural (pp. 193-218). São Paulo: Brasiliense.

Racioppi, V. (1936). Defesa da cidade monumento nacional. In Instituto Histórico de Ouro Preto. Primeiro centenário do Visconde de Ouro Preto (1836-1936)

- Instituto Histórico de Ouro Preto(pp. 49-54). Rio de Janeiro: Officinas Graphicas do Jornal do Brasil.

Roger, A. (2000). La naissance du paysage en Occident. In H. A. Salgueiro (Org.), Paisagem e arte: a invenção da natureza, a evolução do olhar (pp. 33-39). São Paulo: CBHA/CNPq/FAPESP.

Ronai, P. (1953, 05 de abril). Lembranças de Ouro Preto. O Estado de São Paulo, p. 47.

Ruas, E. (1950). Ouro Preto. Rio de Janeiro: Imprensa Nacional.

Santos, P. (1951). Subsidios para o estudo da arquitetura religiosa em Ouro Preto. Rio de Janeiro: Kosmos.

Schama, S. (1996). Paisagem e memória. São Paulo: Companhia das Letras.

Trindade, G. (1948). Pequeno guia de Ouro Preto. Ouro Preto: Casa Malta.

Trindade, R. (1951). São Francisco de Assis de Ouro Preto. Rio de Janeiro: MES/SPHAN

Urry, J. (1996). O olhar do turista, lazer e viagens nas sociedades contemporâneas, São Paulo: SESC/Nobel.

Vasconcellos, D. (1934). Arte em Ouro Preto. Belo Horizonte: Academia Mineira de Letras. (Publicado originalmente em 1911)

Vasconcellos, S. (1941a, 10 de agosto). O turismo e a história mineira. Correio da Manhã, s/p.

Vasconcellos, S. (1941b). Os primeiros aforamentos e os primeiros ranchos de Ouro Preto. Revista do Patrimônio, 5, 241-257.

Vasconcellos, S. (1977). Vila Rica - formação e desenvolvimento, residências. São Paulo: Perspectiva. (Publicado originalmente 1956)

Vasconcellos, S. (1979). A arquitetura colonial mineira. Barroco, 10, 7-26. (Publicado originalmente em 1956)

Arley Andriolo, doutor em Psicologia Social pela Universidade de São Paulo, é professor no Departamento de Psicologia Social e do Trabalho do Instituto de Psicologia da mesma universidade. Endereço para correspondência: Laboratório de Estudos em Psicologia da Arte; Departamento de Psicologia Social e do Trabalho; Instituto de Psicologia da Universidade de São Paulo; Av. Prof. Mello Moraes, 1721, Bloco A, sala 115; Cidade Universitária; São Paulo, SP; CEP: 05508-900. Tel. (11) 3091-4184. E-mail: a.a.andriolo@ gmail.com 